\title{
Re-engineering Inter Company Processes Through Partnership Networks
}

\author{
S. Crom, J. Julian, T. Kuhlmann, B. Hirsch \\ BIBA - Bremen Institute of Industrial Technology and Applied Work \\ Science at the University of Bremen \\ Hochschulring 20, 28359 Bremen, Germany \\ Tel. +494212185582; Fax: +494212185510 \\ e-mail:km@biba.uni-bremen.de
}

\begin{abstract}
In the future the potential of many firms for improvement lies in the inter-company processes of the supply chain. The objective must be to create partnership networks. This paper outlines their strategic benefits and explains the re-engineering process required in order to achieve these new structures.
\end{abstract}

\section{Keywords}

Business process re-engineering, inter company processes, partnership networks, supply chain

\section{INTRODUCTION}

In the last decade, companies have made enormous progress in becoming more globally competitive by implementing Total Quality, re-engineering processes and restructuring their organizations. Simultaneously, customers are enjoying more and more choices in their purchasing decisions, they have access to information about competitive offerings never before available, and they expect nothing less than impeccable customer service.

In short, it is now a competitive necessity to both increase efficiencies and deliver greater service to customers by providing unique value. These dual management imperatives, among others, have led to these times being described as "an era of no tradeoffs" (Ciampa, 1994). Although many companies have focused on increasing efficiency through re-engineering, there has been a management bias towards downsizing and retrenchment as opposed to seeking new opportunities to grow by providing unique value to customers (Hamel \& Prahalad, 1994).

The necessity of providing superior customer value, although almost a truism today, has recently received a great deal of attention, most likely because traditional re-engineering is by 
nature internally focused ${ }^{1}$. As defined by John Guaspari, value as the ratio of what the customer "gets" to what it "costs" over the life of the product or service (Guaspari, ). What the customer "got" includes the combination of product, service, and intangibles and is relative to customer expectations. The "cost" includes price, time, and other intangibles. Each company must choose the unique blend of gots and costs most suited to winning over the customers it chooses to serve. More important, each company must structure its operations - or re-engineer if necessary - to be able to deliver its value it promises most effectively.

Recently, companies have begun to find that they can not only reduce the costs in the value equation, but that they can increase customer gots through the improvement of key processes that manage and deliver the flow of products, services, and information to customers (Christopher, 1994). In fact, it is becoming increasingly clear that the next "step function" improvement for many firms lies in looking at these processes across company boundaries in the supply chain (Crom, 1994). We call this inter-company process re-engineering.

The opportunity to improve performance by simplifying, harmonizing and integrating activities between companies, inter company re-engineering, is potentially great. Bringing new products to market in half the normal time, cutting total inventories by $75 \%$, reducing scrap costs by 50\%, 100\% on-time deliveries are all realistic performance targets if we work within the context of a partnership network of all the players involved in developing and delivering a product or service to a specific customer.

Because of the strategic opportunities - and the potential risks - that partnerships present, several issues must be addressed by senior management before undertaking such an effort. Specifically, how will it contribute to the firm's value proposition to customers? What are the major benefits to the firm? With whom should partnerships be developed and how many should be developed at one time? We will look at answers to these questions next.

\section{RE-ENGINEERING INTER COMPANY PROCESSES}

\section{Partnerships Must Support each Firm's Value Proposition}

In their book "The Discipline of Market Leaders", Treacy and Wiersema (1994) point out that companies cannot succeed by trying to be "all things to everybody". They must find unique value that they alone can deliver to customers. The authors have identified three "value disciplines", each focusing on a dimension of value which companies can use "to stake market reputation over the long-term": operational excellence, customer intimacy, and product leadership. According to the authors, operationally excellent companies are not innovators or relationship builders, but they provide the best price and the most convenience for customers. Product leaders simply find ways for their products to perform better and be more innovative than the products of others. Customer intimate companies cultivate relationships and specialize in satisfying unique needs through close relationships with customers.

Clearly, as Treacy and Wiersema claim, an organization's core processes, culture, and management systems must support the chosen value proposition to customers. The failures of re-engineering efforts are well documented and lie in large part with management's inability to fully understand the changes needed to become more competitive and the level of commitment

\footnotetext{
1 Treacy and Wiersema (1994) suggest that market leaders redefine value "by raising customer expectations in the one component of value they choose to highlight".
} 
these changes sometimes require ${ }^{2}$. It follows, then, that before pursuing partnerships for intercompany re-engineering, the firm must fully understand its value proposition and how intercompany re-engineering will bolster its ability to deliver this value to its customers.

Figure 1: Benefits of Partnership Networks

\begin{tabular}{|c|c|c|}
\hline \multicolumn{3}{|c|}{ 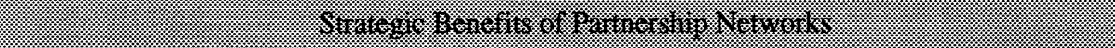 } \\
\hline $\begin{array}{l}\text { Value Discipline of the } \\
\text { Firm }\end{array}$ & Customer Partnership Benefits & Supplier Partnership Benefits \\
\hline Customer Intimacy & $\begin{array}{l}\text { - Continuous learning about } \\
\text { customer's unique require- } \\
\text { ments } \\
\text { - Stronger cultural understand- } \\
\text { ing of the specific customer's } \\
\text { needs } \\
\text { - Support the customer to } \\
\text { implement new products and } \\
\text { services }\end{array}$ & $\begin{array}{l}\text { Collaboration with external } \\
\text { expertise to design and intro- } \\
\text { duce individual customer } \\
\text { solutions } \\
\text { - Supplier responsiveness to the } \\
\text { individual needs of the firm's } \\
\text { customers }\end{array}$ \\
\hline Operational Excellence & $\begin{array}{l}\text { Source for understanding } \\
\text { demand patterns to optimize } \\
\text { logistics and inventory costs } \\
\text { High-volume, low variety } \\
\text { opportunities with specific } \\
\text { customers are a steady source } \\
\text { of cashflow to fund greater } \\
\text { economies of scale }\end{array}$ & $\begin{array}{l}\text { Accurate, predictable incom- } \\
\text { ing shipments that enable low } \\
\text { inventories } \\
\text { Streamlined, low cost pur- } \\
\text { chasing and receiving } \\
\text { processes } \\
\text { Purchased product confor- } \\
\text { mance quality }\end{array}$ \\
\hline Product Leadership & $\begin{array}{l}\text { Source for understanding } \\
\text { demand patterns to ensure } \\
\text { product availability } \\
\text { Source for market feedback } \\
\text { information on product } \\
\text { performance } \\
\text { - Source for active } \\
\text { experimentation with new } \\
\text { product ideas }\end{array}$ & $\begin{array}{l}\text { Responsive, flexible deliveries } \\
\text { that support end-product } \\
\text { availability } \\
\text { - Collaboration with suppliers' } \\
\text { expertise in the design and } \\
\text { introduction of new products } \\
\text { - Supplier responsiveness to } \\
\text { product modifications }\end{array}$ \\
\hline
\end{tabular}

\section{Major Benefits of Developing Supply Chain Partners}

The figure above outlines the strategic benefits that companies following each of the three value disciplines can expect from pursuing inter-company re-engineering partnerships. We

2 James Champy (1995) caustically describes fallen companies like GM, IBM, and PanAm: "Like arrogant navigators, their managers have to feel the surf crashing right over the bows before they change course. Until then, the stick to the methods that gave them mastery." 
define strategic benefits as those that directly support a company's value discipline. Secondary benefits are those that do not directly support the firm's value discipline but nonetheless benefit the firm.

For example, the strategic benefits of supply chain relationships to a customer intimate firm lie in the close relationships it develops with customers. Secondary benefits for this firm would include productivity improvements and cost reductions. On the other hand, the operationally excellent company would find strategic value in the productivity improvements associated with supply chain partnerships (see Figure 1).

The questions of which firms to select and how many with which to partner can be answered within the context of understanding the above benefits for individual firms.

\section{Selecting Partners for Inter-company Re-engineering}

The process of selecting and working with supply chain partners is critical to its success. Thought of as an inter-company team effort, we can build on the well researched criteria for successful teams (Shunk), namely: a common goal, well defined and accepted roles, effective procedures for decision making and communication, compatible and complementary values of the individuals involved. That is, provided that the parties involved have similar management philosophies (e.g., Supply Chain Management) and values i.e., the "chemistry" between senior managers is right, well defined goals, roles and procedures for working together go along way to supporting the success of a cooperative venture. Companies can begin the process of selecting partners by proactively looking at the compatibility of their potential goals and roles within the context of a supply chain partnership. While we suggest pursuing a pilot project with an existing supplier with whom a positive relationship already exists, the entire supply base should be reviewed with an eye to developing partnerships with the best suppliers available not just the ones you are currently doing business with.

\section{Company Goal and Role Compatibility}

Each firm should clarify its value proposition to its customers and make the benefits they expect from the relationship explicit before the goals of the relationship are established. The more the benefits to both parties support each party's intended value discipline as outlined above, the more value the relationship will have for each party and the longer it will thrive.

For example, a company pursuing product leadership will value a supplier partner who can provide responsive, flexible deliveries that support end-product availability and who can offer innovative solutions to their sourcing needs. A company pursuing customer intimacy would value the opportunity to satisfy these needs through a close partnership because of its ability to provide unique solutions and grow its business with this customer.

Providing the value propositions of each firm are well understood, the goals can be developed for mutual benefit. As business results begin to move towards the established goals, the relationship will reinforce itself allowing the partners to grow their respective businesses together.

\section{How Many Network Partners Should a Company Develop?}

Deciding on the number of supply chain partners to develop depends entirely on each company's business needs. The first question is which suppliers would you consider as sole source suppliers? Of those, which are best suited as partners for inter-company re-engineering? What can be said is that, because of the time and energy involved with developing partners, the rule of thumb that "the fewer the better" probably holds true here. For example, a company 
with a limited product line pursuing customer intimacy may require only one or two customer partnerships. However, a large corporation with a broad product line pursuing customer intimacy may require many such partnerships in order to sustain its investment in a broad array of products.

\section{How can a team be developed and maintained across company and national boundaries?}

Having identified a concrete, measurable benefit two companies can achieve more easily by working together, the next step is to build the working teams. Before tasking the teams to further diagnose and re-design a process, they should learn more about the individual learning styles of the members of the teams. An inter-cultural team should be more aware of the stereotypes they have of each other because of national origin (Trompetaars). Once different learning styles, behaviors and norms have been identified and discussed, the group establishes its own groundrules for working together (e.g., when consensus is appropriate and when it isn't, how to manage conflict, how to manage meetings, etc.) Likewise a contract of expectations and groundrules is established between the teams and an inter-company Steering Committee which sponsors the teams, provides over-sight. The Steering Committee plays a critical role in providing the teams "air cover" as they encounter the inevitable political barriers and resistance that come with breakthrough improvement efforts.

\section{What re-engineering methodology should the inter-company teams use?}

The methodology we subscribe to is based on the following approach: first eliminate non-value added steps, second simplify what remains, third systematize it, then finally automate. As with $\mathrm{CIM}$ and $\mathrm{CAD} / \mathrm{CAM}$ the temptation is all to great to see new technology as the panacea of all our process problems. One manager involved in a re-engineering effort even tried to "instill a sense of discipline" into people and the process by automating it, i.e., forcing people to complete various screens on the computer before passing on to the next step (transaction) in the process. Our experience is that listening to the process itself by collecting data about nonvalued added steps and quality problems is the more pragmatic approach. With an "as-is" process map in hand, created by the people who do the work, one can then imagine (brain storm) the ideal process. At that point team members should be made aware of the impact new technology could have on eliminating non-value added steps (customers entering their own orders on-line) and/or creating new capabilities heretofore unimagined (configuring new products in front of the customers using a lap-top computer). In most cases, breakthrough improvements come from getting those closest to everyday problems together to solve the myriad of small problems that have accumulated over time. Because problems are often due to lack of coordination between departments it is especially important that middle managers be involved in the steps described below.

The specific steps an re-engineering team should go through are:

1. Diagnose existing processes, practices and the organization.

2. Benchmark best practices in critical processes, capabilities and organization structures.

3. Design the ideal processes, practices and organization emphasizing the integration of supplier and customer activities.

4. Identify implementation barriers that have to be overcome. 
5. Specify the best processes, practices and organization and the right implementation sequence given the company's climate and circumstances.

6. Develop implementation plans with subgroups of the entire company as well as customers and suppliers.

7. Implement new processes on a pilot basis.

8. Develop and implement plans for full implementation including organizational and other changes needed (e.g. information systems) to support new material and information flows throughout the new inter-company processes.

Rather than "blowing a process up" (along with the people involved) and starting over again with "a clean sheet of paper," our experience is that given the right tools, structured approach and management support, people involved in the process today can redesign processes while improving the organization climate - call it "accelerated evolution" rather than revolution.

What training and consulting tools can be used to build and maintain an inter company community, dialogue and consensus building?

The principle to keep in mind is that partnerships are based on relationships, relationships are based on trust, and trust is build over time through common experience. To that end a workshop design is presented in Figure 2 that forms the foundation for re-engineering inter company processes. The intention is that this series of re-engineering workshops is one element, usually a first step, in an overall strategy for building a partnership network. In the workshop steps 1 through 4 outline above can be accomplished at a high level. Thereafter, both companies can appoint project teams to diagnose, benchmark, design and overcome problems at a detailed level.

There are several criteria that have to be met for the following inter company re-engineering workshops to make sense, the companies involved have to:

- have an existing relationship that is significant and strategically important to both companies,

- senior managers from both companies must share the belief that more is to be gained by working collaboratively than working in traditional adversarial ways,

- both companies must be ready to commit resources to a re-engineering effort.

If those pre-requisites are met, then the following workshops help identify the potential benefit of working collaboratively and motivates key stakeholders in both companies to participate in a joint re-engineering effort. 
Objective: To identify the potential overall benefits that could come from jointly working on improvement opportunities.

Scope: The process to be focused on starts with the receipt of an order from a Company A customer through placing an order with Supplier B for product through production and into Company A's finished good inventory.

\section{Workshop}

Design: Using Product XYZ as an example, the three one day workshops are devoted to identifying opportunities, quantifying them and implementing "quick win" ideas.

Day 1: 1. Conduct Workshop I - The "As Is" \& Ideal Process.

- review the history and current business needs of each company

- map existing processes

- discuss the principles of supply chain management

- imagine the ideal process

- brainstorm quick wins

- identify further data to be gathered by small inter company teams

2. Walk the process together as inter company teams to complete process maps, verify quick wins ideas and collect additional data on opportunities.

Day 2 3. Conduct Workshop II - Redesign:

- present existing processes and data gathered

- expand on the ideal process

- present "best practices" in managing similar inter company processes

- $\quad$ expand the list of quick win ideas

- $\quad$ prioritize the quick win list

- $\quad$ select quick wins to pursue as small inter company teams

- agree on how data should be summarized to show

- potential improvement benefits

4. Work on quick win ideas and data summarizing as inter company teams.

Day 3 5. Conduct Workshop III - Opportunities and Quick Wins.

- present the summaries of improvement potential and draft plan to capture those opportunities

- report progress and results of quick win teams

- decide whether and how to pursue other opportunities and quick win ideas

- $\quad$ identify next steps

Figure 2: Inter-Company Supply Chain Management Workshop 
Re-engineering the Enterprise

\section{SUMMARY}

To succeed, inter-company re-engineering efforts are based on companies working together with clear and compatible business strategies, either operational excellence, product leadership or customer intimacy. Critically important is that the companies involved have a relationship that is significant and strategically important to both companies. Senior managers from both companies must share the belief that more is to be gained by working collaboratively than working in traditional adversarial ways. Both companies must be ready to commit resources to a re-engineering effort. If that is the case, the opportunity to improve performance by simplifying, harmonizing and integrating activities between companies, inter company reengineering, is potentially enormous. Start with one or two core processes and relationships since the first teams will encounter inevitable political resistance that will require the time and attention of senior managers to resolve as well as a considerable dedication of manpower to inter-company working teams. To demonstrate the potential benefits and create a common understanding of inter-company re-engineering conduct a three day workshop with key managers from the companies involved. This starts the process of relationship and trust building. As working groups are established to capture the biggest opportunities, train them in how to work effectively as a team. Take the time to identify the natural tension between learning styles and nationalities that any inter-company, inter-country team will encounter. Give them the tools and support (Steering Committee) to be self-managing. Follow a pragmatic re-engineering approach and first eliminate non-value added steps, second simplify what remains, third systematize it before automating. Look for information technology to play a support role in both the process of working together and the introduction of new capabilities that help deliver the value promised to customers.

\section{REFERENCES}

Champy, J. (1995) Re-engineering Management: The mandate for new leadership. Harper Collins Publisher, New York

Ciampa, D. (1994) The era of no tradeoffs. Leadership report. Rath\&Strong, Inc., Boston.

Cristopher, M. (1994) Logistics \& supply chain management. Richard D. Irwin Inc, New York.

Crom, S.; Kuhlmann, T.; K. Thoben and Hirsch, B. (1994) Partnership networks: A model for future production structures, in Proceedings on Advanced Logistics, 27th ISATA, Aachen.

Hamel, G. and Prahalad, C. (1994) Competing the future. Harvard Business School Press, Boston.

Treacy and Wiersema (1994) The discipline of market leaders, Addison Wesley Publishing, New York

\section{BIOGRAPHY}

\section{Steven E. Crom}

Mr. Crom received his Bachelor of Arts degree in economics and management with honours from Beloit College. He studied international economics at the London School of Economics and Political Science and received his Masters in Business Administration from the University of Chicago. Mr. Crom works with Rath \& Strong clients in leading and implementing Just-InTime and Total Quality efforts in order to help them create greater customer value. 
Since 1994 he is a research scientist at BIBA, where he is completing his Ph.D. in Economics.

\section{Jerry L. Julian}

Mr. Julian earned his Bachelor's degree in Industrial Engineering from the School of Engineering \& Applied Science at Columbia University. He also received an M.B.A. in General Management from the Kenan-Flagler Business School at the University of North Carolina in Chapel Hill.

Mr. Julian has particular expertise in the strategic application of information technology as an enabler of organization change, improved resource productivity, and market responsiveness.

Mr. Julian is Certified in Production \& Inventory Management (CPIM) by the American Production and Inventory Control Society (APICS). At the moment he is working as a consultant at Rath\&Strong.

\section{Thorsten Kuhlmann}

Dr. Thorsten Kuhlmann is research scientist at the BIBA since 1989. At the BIBA, he is in charge of the department "Logistics, Distributed Production".

Dr. Kuhlmann received his M.Sc. degree in business und engineering in 1989 at the University of Hamburg and Technical University of Hamburg-Harburg and his Ph.D at the University of Bremen. His research field covers logistics, production planning \& control and the design of software systems for production management. His special interests are focused on the problem of distributed, inter-organisational production.

He worked as segment manager and workpackage manager in a number of national and European research projects.

\section{Bernd E. Hirsch}

Prof. Dr.-Ing. Bernd E. Hirsch, professor for production systems design, management and control at the University of Bremen and Director of BIBA, the Bremen Institute of Industrial Technology and Applied Work Science at the University of Bremen.

He received his degree in mechanical engineering in 1965, his doctorate at Aachen Technical University in 1969 and a Honorary Professorship at Hannover University in 1979. His professional career includes fourteen years of corporate production management experience in European aerospace industry. He has authored many published papers and is member of the International Federation of Information Processing (IFIP) Working Group 5.7.

His research interests focus on production and automation technology, human-centered CIM, one-of-a-kind as well as distributed manufacturing and technology management and transfer functions. 